\title{
Analisis Loyalitas Agen Biasa dan Agenstok Menggunakan Model RFM (Recency,Frequency, Monetery) dan Algoritma K-Medoids pada BC 4 HPAI Pekanbaru
}

Loyalty Analysis of Ordinary Agents and Stock Agents Using the RFM Model (Recency, Frequency, Monetary) and K-Medoids Algorithm on BC 4 HPAI Pekanbaru

Siti Monalisa ${ }^{1}$, Imelda Erza ${ }^{2}$

${ }^{1,2}$ Program Studi Sistem Informasi, Universitas Islam Negeri Sultan Syarif Kasim Riau E-mail: siti.monalisa@uin-suska.ac.id ${ }^{1}$,imeldaerza@ gmail.com²

\begin{abstract}
Abstrak
PT.Herbal Penawar Alwahida Indonesia (HPAI) merupakan perusahaan bisnis halal network di Indonesia yang fokus pada produk-produk herbal. Salah satu BC (Bussines center) HPAI yang terdapat di pekanbaru yaitu,BC 4 HPAI beralamat dijalan Melati III No.4 Bina Widya,Panam. Berdasarkan obeservasi yang dilakukan, data transaksi pelanggan pada tahun 2019 di BC 4 mencapai 1000-2000 transaksi setiap bulannya, yang terdiri dari data agen biasa dan agenstok. Berdasarkan wawancara dengan owner BC 4 HPAI Pekanbaru, masalah yang terjadi yaitu pihak BC 4 HPAI belum bisa mendapatkan informasi dari setiap data agen biasa dan agen stok,mana pelanggan yang potensial dan loyal terhadap perusahaan. Sehingga menyebabkan pihak BC akan sulit untuk menentukan strategi pemasaran yang tepat dalam memanfaatkan kesempatan atau peluang yang ada dalam pemasaran. Mengatasi permasalahan tersebut, penelitian ini menerapkan strategi customer Relationship Management (CRM) yaitu menggunakan Metode RFM untuk mengetahui karakteristik atau prilaku agen biasa dan agenstok kemudian Clustering menggunakan Agoritma K-Medoids untuk pengelompokan sesuai kemiripan karakteristik agenbiasa dan agenstok yang telah didapat sebelumnya. Dengan percobaan 2 cluster sampai dengan 7 cluster, menghasilkan 2 Cluster Terbaik agen biasa dan 3 Cluster Terbaik agenstok berdasarkan DBI (Davies Bouldin Index). Dengan masing-masing nilai DBI terbaik 0.228 agen biasa dan 0.234 agenstok. Hasil tertinggi 2 cluster agen biasa berada pada cluster 1 dengan tipe pelanggan Superstar yang memiliki 472 customer loyal. dan hasil tertinggi dari 3 cluster agenstok berada pada cluster 3 dengan tipe pelanggan Superstar yang memiliki 60 customer loyal.
\end{abstract}

Kata kunci : Agen Biasa, Agenstok, Algoritma K-Medoids, DBI, RFM

\begin{abstract}
PT.Herbal Penawar Alwahida Indonesia (HPAI) is a halal network business company in Indonesia that focuses on herbal products. One of the HPAI BC (Bussines Center) in Pekanbaru, namely, BC 4 HPAI having its address at Jalan Melati III No.4 Bina Widya, Panam. Based on the observations made, customer transaction data in 2019 in BC 4 reached 1000-2000 transactions each month, consisting of data from ordinary agents and stock agents. Based on an interview with the owner of BC 4 HPAI Pekanbaru, The problem that occurs is that the BC 4 HPAI has not been able to get information from any data from ordinary agents and stock agents, which are potential customers and are loyal to the company. So that it causes the BC will find it difficult to determine the right marketing strategy in taking advantage of opportunities or opportunities that exist in marketing. To solve this problem, this final project applies a customer Relationship Management (CRM) strategy, which is to use the RFM method to determine the characteristics or behavior of ordinary agents and stock agents then clustering using the $K$ Medoids Agorithm for grouping according to the similarity of characteristics of ordinary agents and stock agents that have been previously obtained. With each of the best DBI values are 0.228 ordinary agents and 0.234 stock agents. The highest result is 2 regular agent clusters in
\end{abstract}


cluster1with thetypeofcustomerSuperstar whichhas472loyalcustomers. and thehighestresults from 3 clusters of stock agents are in cluster 3 with the type of Superstar customers who have 60 loyal customers.

Keywords : DBI, K-Medoids Agorithm, Ordinary Agents, Stock Agents, RFM

\section{PENDAHULUAN}

PT Herbal Penawar Alwahida Indonesia (HPAI) adalah perusahaan bisnis halal network yang berfokus pada produk-produk herbal di Indonesia. Memiliki 87 jenis produk, yaitu produk obatan herbal, produk keperluan rumahan seharihari, produk cosmetik, dll. Data tahun 2016 tercatat sebanyak 114 Business Center (BC) HPAI di seluruh Indonesia, lima diantaranya terdapat di Provinsi Riau dan Kepulauan Riau [1]. Salah satu BC yang terdapat di pekanbaru yaitu ,BC 4 HPAI beralamat di jalan Melati III No.4 Bina Widya, Panam. Berdasarkan obeservasi yang dilakukan, data transaksi pelanggan pada tahun 2019 di BC 4 lebih banyak yaitu mencapai 10002000 transaksi setiap bulannya dibandingkan BC 3 HPAI Pekanbaru yang hanya mencapai 600900 setiap bulannya.

Data transaksi pelanggan yang ada pada $\mathrm{BC} 4$ terdiri dari 2 data transaksi, yaitu agen biasa dan agenstok. Berdasarkan wawancara dengan owner BC 4 HPAI Pekanbaru, menyatakan bahwa pengumpulan data pada BC 4 HPAI didapat berdasarkan transaksi 600 agen yang telah mendaftar di BC 4 dan juga dari transaksi agen lainnya yang telah mendaftar di BC yang ada di Indonesia yang melakukan pembelian produk di BC 4 . Namun, data itu hanya berguna sebatas perhitungan omset saja. Masalah yang terjadi yaitu pihak BC 4 HPAI belum bisa mendapatkan informasi dari setiap data agen biasa dan agenstok, mana pelanggan yang potensial dan loyal terhadap perusahaan. Dengan ketidaktahuan pihak BC terhadap kerakteristik setiap agen biasa dan agenstok yang dimilikinya, menyebabkan pihak BC akan sulit untuk menentukan strategi pemasaran yang tepat dalam memanfaatkan kesempatan atau peluang yang ada dalam pemasaran [2].

Menyikapi permasalahan di atas untuk mengetahui, mempertahankan, serta meningkatkan loyalitas pelanggan, penelitian ini memberikan solusi yaitu dengan menerapkan stategi customer Relationship Management (CRM) [3]. CRM merupakan satu dari beberapa strategi bisnis yang bertujuan meningkatkan keuntungan, penghasilan serta kepuasan pelanggan dengan melakukan segmentasi pelanggan dan cara memberikan perlakuan terhadap konsumen [4]. Tujuan proses segmentasi konsumen adalah untuk mendapatkan bagaimana perilaku konsumen dan mengaplikasikan strategi pemasaran yang sesuai hingga mampu menghasilkan keuntungan dalam perusahaan [5]. Agar hasil segmentasi lebih tepat sasaran maka segmentasi pelanggan pada penelitian ini dilakukan langsung terhadap agen biasa dan agenstok pada BC 4 HPAI menggunakan model RFM (Recency,Frequency,Monetary) [6].

RFM terdiri dari tiga kriteria Nilai recency(kapan terakhir transaksi dilakukan), frequency (jumlah transaksi yang dilakukan pelanggan), monetary (besarnya nilai transaksi yang dilakukan)[3]. Metode RFM dipilih karena metode ini efektif untuk melakukan segmentasi pelanggan dan objektifitasnya baik [7]. Pada metode ini dilakukan ekstraksi atribut data sesuai kebutuhan dan data yang digunakan adalah data yang telah melalui tahap pengumpulan dan praproses data. kemudian dilanjutkan proses clustering [8].

Klasterisasi atau Clustering adalah cara pengelompokan secara alamiah sebuah data yang didasari dengan kemiripan objek data serta untuk mengurangi kemiripan terhadap cluster lain [3]. Clustering akan digunakan untuk mencari agen biasa dan agenstok mana saja yang memiliki prilaku yang sama. Kemudian akan dilakukan pengelompokan sesuai karakteristiknya. Algoritma clustering yang diusulkan pada penelitian ini yaitu K-Medoids. Alasan memilih algoritma KMedoid yaitu karena medoid bisa menghasilkan nilai rata-rata dari objek dalm sebuah cluster yang dijadikan titik acuan serta mampu mengatasi kekurangan algoritma K-Means yang sensitive pada noise dan outlier [9].

Pada penelitian ini akan akan dilakukan segmentasi terhadap 2 bentuk pelanggan yaitu 
agen biasa dan agenstok untuk mencari pelanggan yang Loyal terhadap perusahaans, dengan menggunakan model RFM dan algoritma $K$-medoid untuk clusternya. Berdasarkan penelitian sebelumnya oleh Tsiptsis dan Chorianopoulos (2011) [10] menyatakan bahwa segmentasi pelanggan berdasarkan nilai RFM, dicabangkan menjadi 6 karakteristik diantaranya Superstar, Golden customer, Typical customer, Occational customer, Everyday shopper, dan Dormant customer. Penelitian ini diharapkan dapat membantu perusahaan yaitu BC 4 HPAI dalam menemukan pelanggan yang loyal serta menerapkan strategi pemasaran yang tepat untuk setiap bentuk pelanggan yang ada, dan juga pastinya akan memberikan keuntungan untuk perusahaan dalam meningkatkan kualitas dan loyalitas pelanggan terhadap perusahaan.

\section{METODE PENELITIAN}

Objek penelitian ini adalah pelanggan agen biasa dan agenstok BC 4 HPAI Pekanbaru. Data penjualan BC 4 HPAI Pekanbaru merupakan data primer yang digunakan pada penelitian ini. Penelitian ini melalui lima tahap utama yaitu tahap Perencanaan, tahap Pengumpulan Data, tahap Knowledge Discoveryin Database (KDD), tahap Analisis dan Hasil dan tahap Dokumentasi.

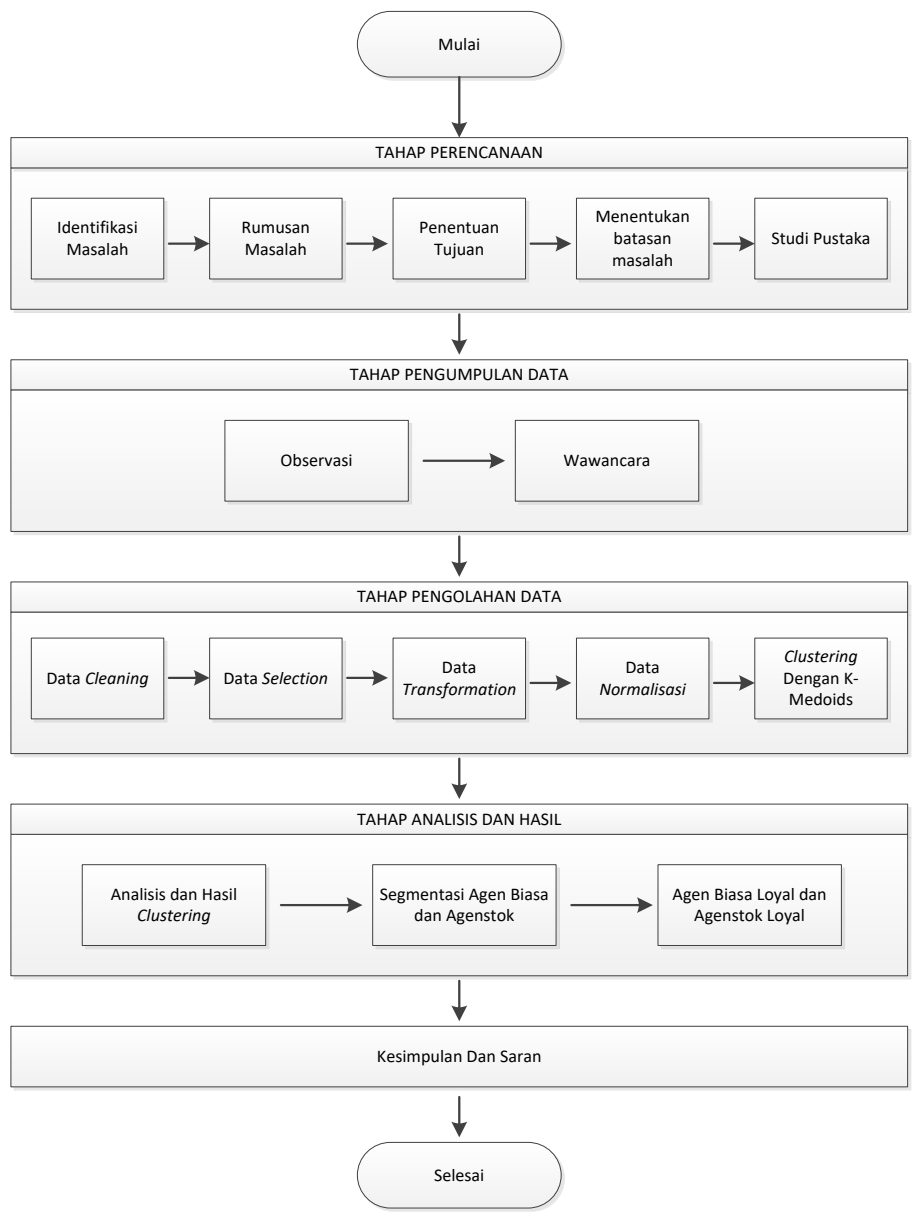

2.1 Agen Biasa dan Agenstok

Gambar 1. Alur Penelitian

Agen biasa yaitu seorangan yang sudah mendaftar menjadi distributor HPAI dengan melakukan minimal 1 kali transaksi produk pada agentok resmi hpai dalam masa 6 bulan (Yulianto dan Hananto,2018). Dan AgenStok yaitu Agen HPAI yang telah memenuhi syarat serta disetujui oleh pihak perusahaan untuk melayani penjualan atau distribusi ritel dari Produk-produk HPAI [11]. 


\subsection{Knowledge Discovery Database (KDD)}

Tujuan dari Knowledge Discovery Database (KDD) adalah menghasilkan informasi baru yang berguna dari kumpulan data didalam basis data yang kemudian dikelola [12]. Proses KDD dijelaskan sebagai berikut :

1. Data Selection. Yaitu Pemilihan (seleksi) data. Data hasil seleksi digunakan dalm proses data mining, kemudian disimpan dalam berkas tertentu yang terpisah dari database operasional.

2. Pre-processing / Cleaning. Proses cleaning ini melakukan pembuangan data duplikat, memeriksa kembali data yang tidak konsisten/inkonsisten,serta memperbaiki kesalahan yang terdapat pada data, seperti kesalahan mencetak.

3. Transformation. Coding adalah proses tranformasi data yang fix untuk proses data mining. Proses coding pada KDD merupakan sebuah proses yang sangat bergantung model jenis atau bentuk informasi seperti apa yang akan dicari atau diinginkan di database.

4. Data Mining. Data mining merupakan proses yang dilakukan untuk mendapatkan bentuk informasi bagus dari data yang sudah terpilih menggunakan cara atau teknik tertentu. Bentuk teknik, model metode, serta algoritma data mining berjumlah banyak jenis dan fungsinya. Pemilihan metode atau algoritma disesuaikan dengan tujuan dan proses KDD seluruhnya.

5. Interpretation / Evaluation. Proses ini bertujuan untuk memeriksa informasi yang sudah sesuai atau tidak dengan fakta atau hipotesa sebelumnya. Bila hasil yang diperoleh tidak sesuai hipotesa, maka bisa mencoba teknik daming lainnya untuk mendapat hasil yang lebih baik dan bisa juga tetap pada hasil sebelumnya.

\subsection{Model RFM (Recency, Frequency dan Monetery)}

Model RFM sering kali dipergunakan dalam segmentasi pasar. RFM mempertahankan informasi tentang terakhir pelanggan belanja (recency), jumlah transaksi pelnggan (frequency), dan seluruh biaya yang dihabiskan selama melakukan transasksi dalam 1 priode (monetary) [13]. Rumus menghitung nilai RFM sebagai berikut:

$$
\text { Skor RFM }=(\text { Recency } \times 100)+(\text { Nilai Frequency } \times 0)+(\text { Nilai Monetery })
$$

\subsection{Clustering}

Clustering yaitu ilmu yang berfokus untuk mengelompokkan data tanpa ada sistem pelabelan kategori. Clustering dimanfaatkan untuk mengelompokkan data yang alamiah sesuai mirip atau tidaknya pada objek data serta meminimalisisr kemiripan dengan cluster lainnya [3].

\subsection{Normalisasi Data}

Setelah memalui Tahap Trnasformasi, dilakukan normalisasi data agar skala data tidak terlalu jauh. Transformasi atribut dijadikan numerik yaitu mulai dari batas terendah 0 dan batas tertinggi 1 . Dalam proses normalisasi data dapat digunakan rumus min max normalitation,untuk memudahkan perhitungan data dengan metransformasikan data ke dalam suatu range. Rumus min max normalzation:

$$
V=\frac{V-\operatorname{Min}}{\operatorname{Max}-\operatorname{Min}}
$$

\subsection{Algoritma K-Medoids}

K-Medoids adalah algoritma yang diwakili oleh cluster yaitu medoid. Alasan memilih algoritma K-Medoid yaitu karena medoid dapat mengambil nilai rata-rata objek pada sebuah cluster yang menjadi titik acuan serta mampu membenahi kekurangan algoritma 
K-Means yang sensitive terhadap noise dan outlier [9]. Berikut adalah alur dari proses Algoritma K-Medoids.

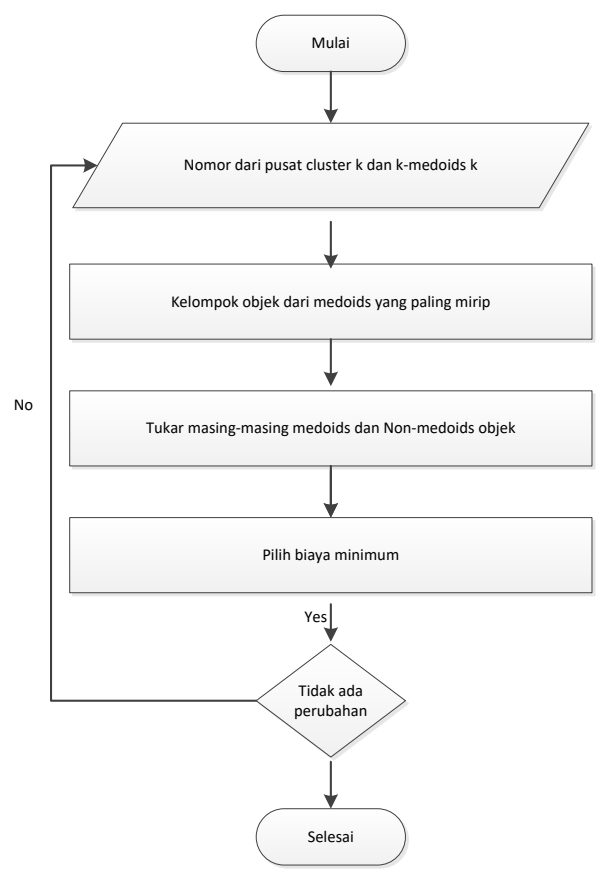

Gambar 2 Alur dari proses Algoritma K-Medoids.

1. Memberi inisial sebanyak $\mathrm{k}$ (jumlah cluster) pada pusat cluster.

2. Rincikan setiap data (objek) ke cluster terdekat menggunakan persamaan jarak Euclidian Distance sebagai berikut.

$$
d(x, y)=\|x-y\|=\sqrt{\sum_{i=1}^{n}\left(x_{i}-y i\right)^{2}}
$$

3. Lakukan pemilihan acak pada setiap cluster untuk dijadikan kandidat medoid baru.

4. menghitung jarak setiap objek cluster dengan kandidat medoid baru.

5. Hitung total simpangan (S) dengan menghitung nilai total distance baru - total distance lama. Jika $S_{i} 0$, maka tukar objek dengan data cluster untuk membentuk sekumpulan k objek baru sebagai medoid.

6. Ulangi langkah sebanyak 3 hingga 5 kali sampai tidak ada perubahan medoid lagi. Dan mendapat cluster serta masing-masing anggota cluster.

\subsection{Davies Bouldin Index (DBI)}

Untuk mementukan jumlah K cluster pada algoritma k-medoids, ada beberapa validitas cluster yang bisa dimanfaatkan. Davies Bouldin Index (DBI) adalah salah satunya. DBI adalah salah satu jalan mengukur validitas cluster dalam pengelompokan yang berbasis partisi berdasarkan value kohesi serta separasi. Rumus DBI dapat dilihat pada persamaan 4 :

$$
D B I=\frac{1}{K} \sum_{i=1}^{K} \max \left(R_{i, j}\right)
$$

Jumlah cluster yang digunkan disimbolkan dengan K. Menguji beberapa nilai K adalah jalan perhitungan DBI. Hasil nilai DBI yang terendah diartikan sebagai $\mathrm{K}$ yang paling bagus dan paling cocok dalam proses clustering algoritma K-Medoids. 


\section{HASIL DAN PEMBAHASAN}

Berdasarkan hasil Wawancara dan observasi di BC 4 HPAI, data yang didapat yaitu rekapan data transaksi penjualan pada bulan januari sampai bulan oktober 2019. Dengan jumlah 15.000 transaksi. Data yang diperoleh merupakan data dari format Pdf yang kemudian di salin kedalam bentuk excel. Berikut adalah sample data transaksi penjualan pada BC 4 HPAI Pekanbaru dapat dilihat pada Gambar 3.1.

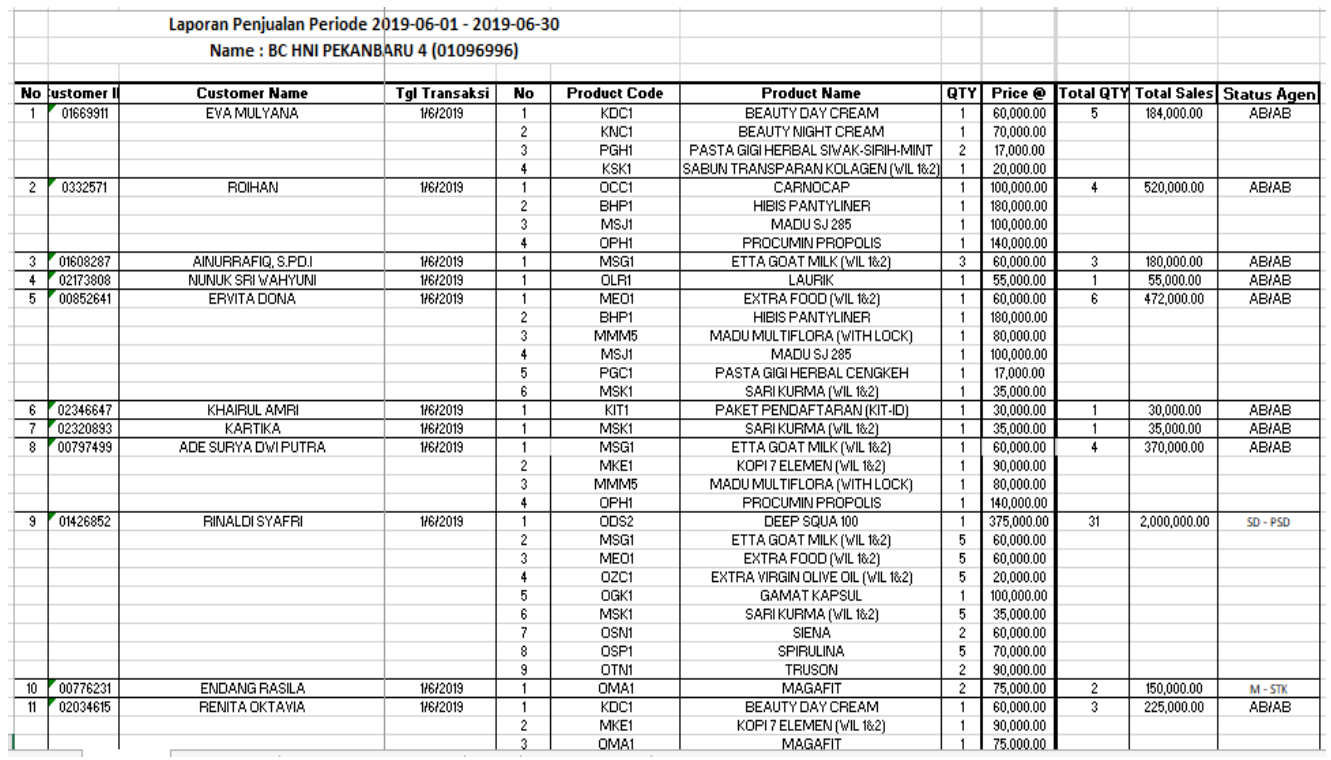

Gambar 3 Sampel Data Transaksi bulan juni 2019

Setelah melalui tahapan Knowledge Discovery in Database (KDD), yaitu tahap data selection, tahap cleaning dan tahap transformasi data ke dalam bentuk kriteria RFM (Recency,Frequeancy dan Monetery) pada masing masing data agen biasa dan agenstok menghasilkan 7.361 data transaksi Agen biasa dengan jumlah pelanggan 533 dan 2.906 data transaksi Agenstok dengan 212 Jumlah pelanggan., maka dilanjutkan proses normalisasi akhir data seperti berikut ni :

Table 1 Normalisasi data RFM Agen biasa

\begin{tabular}{|c|c|c|c|c|}
\hline No & Customer Name & $\begin{array}{c}\text { Normalisasi } \\
\text { Recency }\end{array}$ & $\begin{array}{c}\text { Normalisasi } \\
\text { Frequensi }\end{array}$ & $\begin{array}{c}\text { Normalisasi } \\
\text { Monetery }\end{array}$ \\
\hline 1 & ABDUL MALIK, S.AG & 0.951 & 0.092 & 0.060 \\
\hline 2 & ABDUL RAHMAN & 0.980 & 0.262 & 0.080 \\
\hline 3 & ABDULLAH & 0.990 & 0.538 & 0.584 \\
\hline 4 & ADE ERMA SURYANI & 0.990 & 0.169 & 0.022 \\
\hline & & $\ldots \ldots \ldots \ldots \ldots$ & & ……........... \\
\hline 533 & ZURNELI KURNIA & 0.964 & 0.277 & 0.065 \\
\hline
\end{tabular}

Table 2 Normalisasi data RFM Agenstok

\begin{tabular}{|c|l|c|c|c|}
\hline No & \multicolumn{1}{|c|}{ Customer Name } & $\begin{array}{c}\text { Normalisasi } \\
\text { Recency }\end{array}$ & $\begin{array}{c}\text { Normalisasi } \\
\text { Frequensi }\end{array}$ & $\begin{array}{c}\text { Normalisasi } \\
\text { Monetery }\end{array}$ \\
\hline 1 & ARITA & 0.000 & 0.054 & 0.012 \\
\hline 2 & YUSRUL & 0.469 & 0.162 & 0.123 \\
\hline 3 & ABDUL WAHID & 0.319 & 0.162 & 0.151 \\
\hline 4 & ADNAN DAUD & 0.664 & 0.270 & 0.013 \\
\hline$\ldots \ldots$ & $\ldots \ldots \ldots \ldots \ldots \ldots \ldots \ldots \ldots \ldots \ldots \ldots \ldots \ldots \ldots \ldots \ldots \ldots \ldots \ldots \ldots \ldots \ldots \ldots$ & $\ldots \ldots \ldots \ldots \ldots \ldots$ \\
\hline 212 & ZULKIFLI & $\ldots \ldots \ldots \ldots \ldots$ & 0.216 & 0.033 \\
\hline
\end{tabular}


Setelah melalui proses normalisasi, dilanjutkan dengan proses clustering menggunakan algoritma k-medoids dengan tool Rapidminer. Percobaan dilakukan menggunakan 2 cluster sampai 7 cluster untuk agen biasa dan 2 cluster sampai 7 cluster untuk agenstok bertujuan untuk mendapatkan cluster terbaik.

Berikut adalah proses clustering menggunakan K-Medoids.

1. Menentukan point $\mathrm{k}$ sebagai inisial centroid/nilai tengah (medoid)

Penentuan centroid/nilai tengah (medoid) dibuat sebanyak k cluster pada masing masing data agen biasa dan agenstok. Agen biasa dibagi menjadi dua cluster, maka $\mathrm{k}=$ 2 , Agentok akan dibagi menjadi tiga cluster, maka $\mathrm{k}=3$. Setelah itu, pilih secara acak tiga medoid yang mewakili tiga cluster tersebut. Medoid yang mewakili agen biasa dan agenstok seperti table berikut :

Tabel 3. Medoid Secara Acak dari Dua Cluster Agen Biasa

\begin{tabular}{|l|c|c|}
\hline & CI & C2 \\
\hline Recency & 1,000 & 1,000 \\
\hline Frequency & 1,000 & 0,169 \\
\hline Monetery & 0.997 & 0,155 \\
\hline
\end{tabular}

Tabel 4. Medoid Secara Acak dari Dua Cluster Agenstok

\begin{tabular}{|l|c|c|c|}
\hline & CI & C2 & C3 \\
\hline Recency & 1,000 & 0,195 & 0,938 \\
\hline Frequency & 0,196 & 0,081 & 0,459 \\
\hline Monetery & 0,155 & 0,041 & 0,291 \\
\hline
\end{tabular}

2. Alokasikan setiap data (objek) ke cluster terdekat menggunakan persamaan ukuran jarak Euclidian Distance.

Kemudian mencari poin yang terdekat dengan medoid dengan menghitung jarak vector/cost antar data dengn medoid menggunakan euclidian distance. Masing masing table merupakan sample hanya pada percobaan pertama

Tabel 4. Jarak ke Medoid 1 dan Medoid 2 AB Percobaan Pertama

\begin{tabular}{|c|c|c|c|c|c|}
\hline No & Recency & Frequency & Monetery & C1 & C2 \\
\hline 1 & 0.951 & 0.092 & 0.092 & 0.032 & 0.914 \\
\hline 2 & 0.980 & 0.262 & 0.080 & 0.172 & 0.743 \\
\hline 3 & 0.990 & 0.538 & 0.584 & 0.665 & 0.630 \\
\hline$\ldots$. & $\ldots$ & $\ldots$ & $\ldots$. & $\ldots \ldots$ & $\ldots \ldots$ \\
\hline 533 & 0.964 & 0.277 & 0.065 & 0.187 & 0.730 \\
\hline
\end{tabular}

Tabel 5. Jarak ke Medoid 1, Medoid 2 dan Medoid 3 AS Percobaan Pertama

\begin{tabular}{|c|c|c|c|c|c|c|}
\hline No & Recency & Frequency & Monetery & C1 & C2 & C3 \\
\hline 1 & 0.951 & 0.092 & 0.092 & 0.032 & 0.199 & 1.059 \\
\hline 2 & 0.469 & 0.162 & 0.123 & 0.494 & 0.298 & 0.580 \\
\hline 3 & 0.319 & 0.162 & 0.151 & 0.364 & 0.184 & 0.701 \\
\hline$\ldots .$. & $\ldots$ & $\ldots$ & $\ldots$ & $\ldots \ldots$ & $\ldots \ldots$ & \\
\hline 112 & 0.964 & 0.514 & 0.657 & 1.228 & 1.058 & 0.370 \\
\hline
\end{tabular}

Dilakukan dengan cara yang sama hingga ke data urut 212. Setelah menghitung jarak/cost langkah dilanjutkan untuk menntukan cost/jarak terdekat dengan medoid. Cara menentukan jarak terdekat yaitu dengan membandingkan hasil cost untuk melihat kedekatan/kemiripan data dengan 
cluster. Kedekatan/kemiripan data ke cluster diketahui melalui nilai cost yang terkecil dari perbandingan kedua cost

3. Pilih secara acak objek pada masing-masing cluster sebagai kandidat medoid baru.

Selanjutnya langkah yang dilakukan adalah memilih objek non-medoid atau memilih medoid baru. Ulangi langkah Ini hingga mendapatkan nilai cost paling dekat dengan medoid baru tersebut.

Tabel 6. Medoid Secara Acak dari Dua Cluster Agen Biasa

\begin{tabular}{|l|c|c|}
\hline & CI & C2 \\
\hline Recency & 1,000 & 1,961 \\
\hline Frequency & 1,000 & 0,169 \\
\hline Monetery & 0.997 & 0,143 \\
\hline
\end{tabular}

Tabel 7 Medoid Secara Acak dari Dua Cluster Agenstok

\begin{tabular}{|l|c|c|c|}
\hline & CI & C2 & C3 \\
\hline Recency & 1,000 & 0,673 & 0,832 \\
\hline Frequency & 0,054 & 0,243 & 0,027 \\
\hline Monetery & 0,012 & 0,010 & 0,006 \\
\hline
\end{tabular}

4. Menghitung setiap jarak objek pada masing-masing Cluster dengan kandidat medoid baru.

Pada langkah ini sama halnya dengan langkah ke 2 .

5. Menghitung total simpangan (S) dengan cara menghitung nilai total dari distance baru total distance lama.

Setelah mendapat nilai cost medoid dan medoid baru Agen biasa dan Agenstok, maka langkah selanjutnya yaitu mencari serta mendapatkan selisih antara total cost medoid baru dengan total cost medoid lama. Adapun hasil selisih yang didapat seperti pada Tabel berikut:

Tabel 8. Total Cost Medoid Lama dan Medoid Baru Agen Biasa

\begin{tabular}{|c|c|}
\hline \multicolumn{1}{|c|}{ Percobaan } & Cost \\
\hline Cost Medoid Lama & 110.306 \\
\hline Cost Medoid Baru & 111.907 \\
\hline
\end{tabular}

Selisih cost $=$ Cost medoid baru - Cost medoid lama $=111.907-110.306=1.601$

Tabel 9. Total Cost Medoid Lama dan Medoid Baru Agenstok

\begin{tabular}{|c|c|}
\hline \multicolumn{1}{|c|}{ Percobaan } & Cost \\
\hline Cost Medoid Lama & 67.515 \\
\hline Cost Medoid Baru & 73.221 \\
\hline
\end{tabular}

Selisih cost $=$ Cost medoid baru - Cost medoid lama $=73.221-67.515=5.706$

Jika mendapatkan selisih kurang dari 0, maka cari non-medoid atau medoid baru lagi hingga mendapatkan selisih cost antara medoid baru dan medoid lama lebih dari 0. Jika mendapatkan lebih dari 0 , maka proses clustering berhenti. Hasil pengurangan cost pada percobaan diatas sudah lebih dari 0 maka proses clustering berhenti pada tahap ini dan hasil cluster adalah pada percobaan pertama. Hasil cluster agen biasa dan agenstok dapat dipahami pada Tabel berikut:

Tabel 10. Hasil Cluster Agen Biasa

\begin{tabular}{|c|c|}
\hline Percobaan & Cost \\
\hline Cluster 1 & 472 \\
\hline
\end{tabular}




\begin{tabular}{|l|c|}
\hline Cluster 2 & 61 \\
\hline Total & 533 \\
\hline
\end{tabular}

Tabel 11. Hasil Cluster Agenstok

\begin{tabular}{|l|c|}
\hline \multicolumn{1}{|c|}{ Percobaan } & Cost \\
\hline Cluster 1 & 126 \\
\hline Cluster 2 & 26 \\
\hline Cluster 3 & 60 \\
\hline Total & 112 \\
\hline
\end{tabular}

Berikut merupakan Sample Proses Clustering algoritma $\mathrm{K}$-Medoids menggunakan tools RapidMiner.

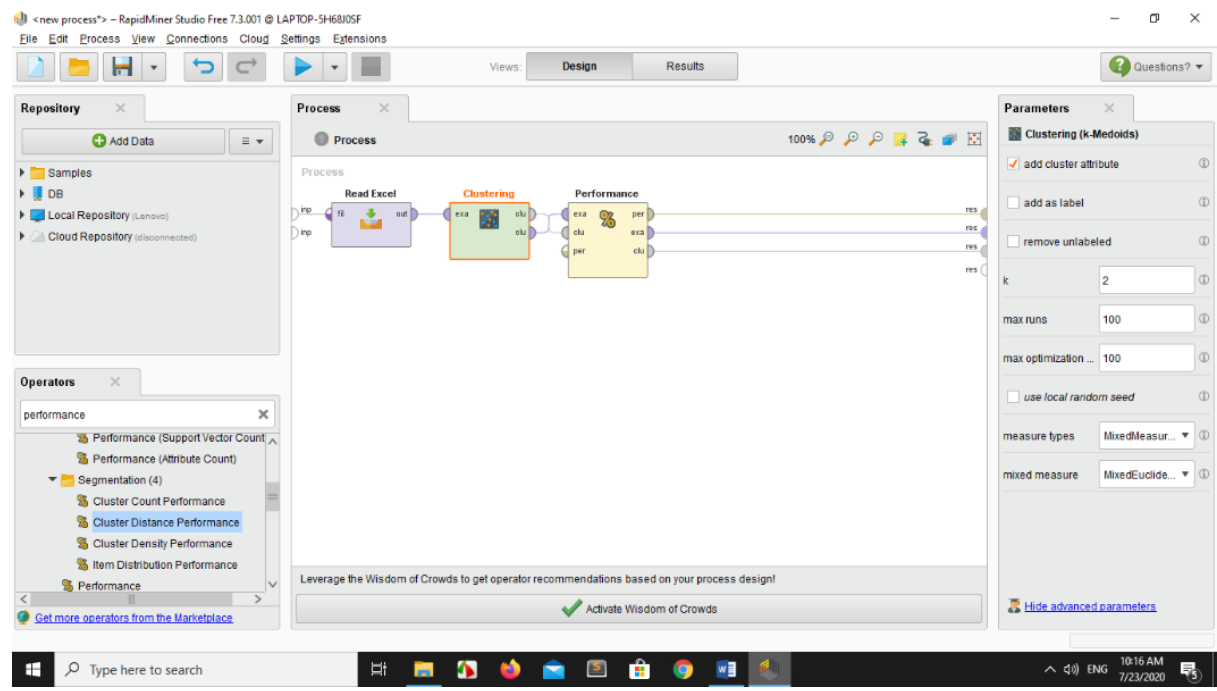

Gambar 4. Proses Awal Penginputan Data pada RapidMiner

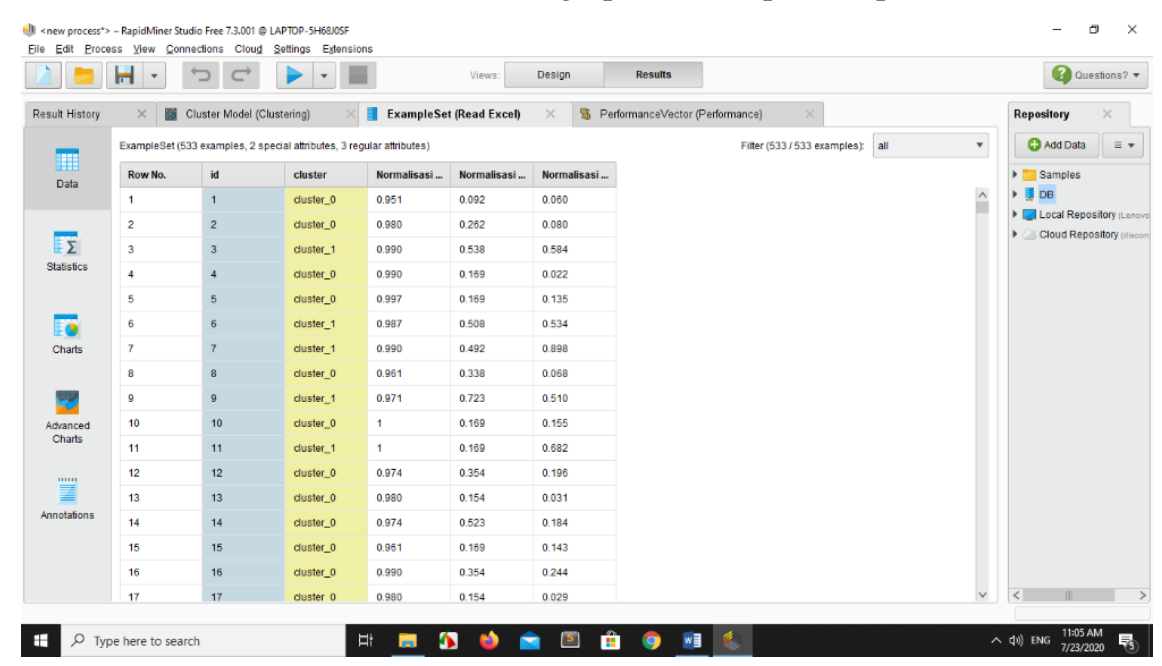

Gambar 5. Hasil Cluster 


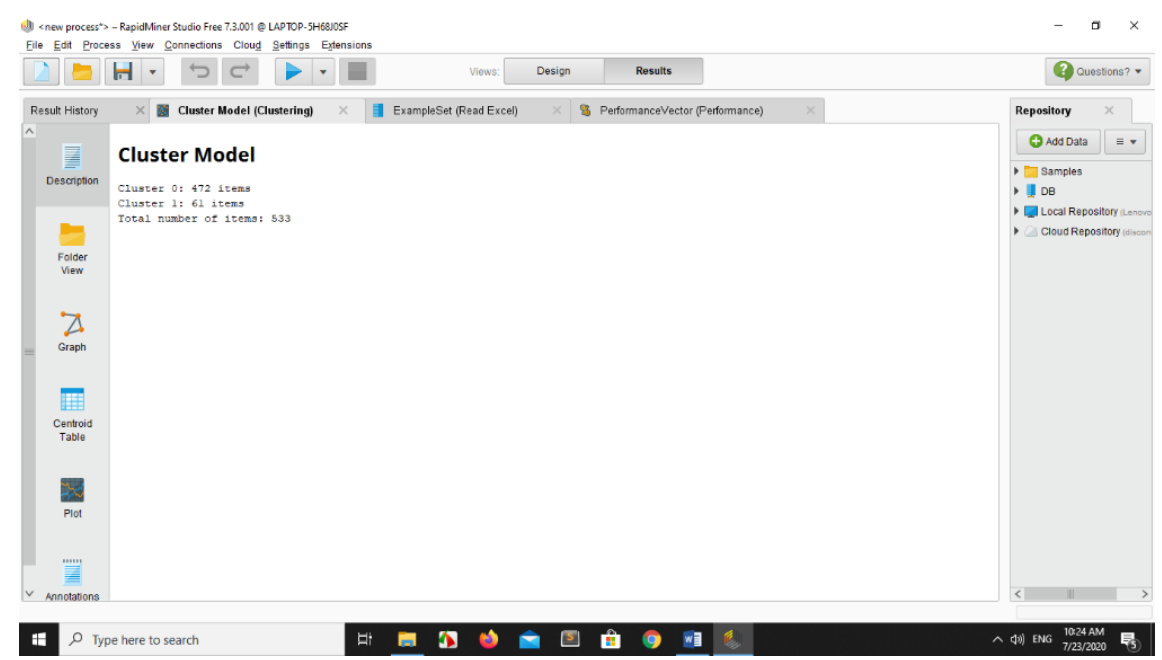

Gambar 6. Hasil 2 Cluster beserta jumlah data per Cluster

Hasil cluster terbaik dari cluster cluster agen biasa dan cluster cluster agenstok ditentukan dengan hasil DBI terbaik dari setiap cluster yang diproses. Berikut adalah hasil DBI terbaik agen biasa dan agnstok :

Tabel 12 Hasil DBI Cluster 1 sampai Cluster 7 Agen Biasa

\begin{tabular}{|c|c|c|}
\hline No & Cluster & Nilai DBI \\
\hline 1 & Cluster 2 & 0.228 \\
\hline 2 & Cluster 3 & 0.341 \\
\hline 3 & Cluster 4 & 0.553 \\
\hline 4 & Cluster 5 & 0.461 \\
\hline 5 & Cluster 6 & 0.455 \\
\hline 6 & Cluster 7 & 0.485 \\
\hline
\end{tabular}

Tabel 13 Hasil DBI Cluster 1 sampai Cluster 7 Agenstok

\begin{tabular}{|c|l|c|}
\hline No & Cluster & Nilai DBI \\
\hline 1 & Cluster 2 & 0.286 \\
\hline 2 & Cluster 3 & 0.234 \\
\hline 3 & Cluster 4 & 0.311 \\
\hline 4 & Cluster 5 & 0.358 \\
\hline 5 & Cluster 6 & 0.385 \\
\hline 6 & Cluster 7 & 0.343 \\
\hline
\end{tabular}

Berdasarkan hasil nilai DBI cluster RFM agen biasa dan agenstok,maka telah didapat nilai DBI terbaiknya. Yang mana nilai DBI yang terendah dari setiau cluster RFM agen biasa dan agenstok merupakan hasil cluster terbaik untuk mengetahui tujuan penelitian ini yaitu mencari pelanggan yang loyal dan yang tidak. Nilai DBI Terbaik pada Cluster agen biasa yaitu pada Cluster 2 dengan DBI 0.228 dan DBI terbaik agenstok yaitu pada cluster 3 dengan nilai DBI 0.234 dapat dilihat pada Table berikut.

Tabel 14 Nilai DBI 0.228 Terbaik Cluster 2 Agen biasa

\begin{tabular}{|c|c|c|}
\hline No & Cluster & Pelanggan \\
\hline 1 & 1 & 472 \\
\hline 2 & 2 & 61 \\
\hline 3 & Total & 533 \\
\hline
\end{tabular}

Tabel 15 Nilai DBI 0.234 Terbaik Cluster 3 Agenstok

\begin{tabular}{|c|c|c|}
\hline No & Cluster & Pelanggan \\
\hline 1 & 1 & 126 \\
\hline 2 & 2 & 26 \\
\hline 3 & 3 & 60 \\
\hline 4 & Total & 212 \\
\hline
\end{tabular}


Berikut sample dari proses pencarian DBI menggunakan tools RapidMiner

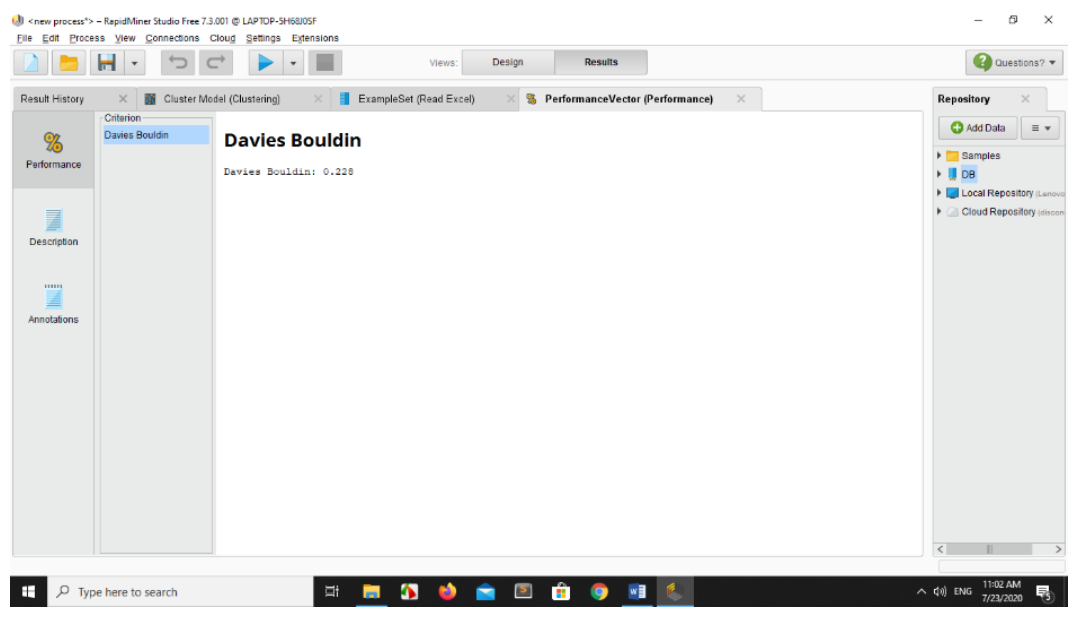

Gambar 7. Hasil 2 Cluster beserta jumlah data per Cluster

Setelah mengetahui pelanggan agen biasa dan agenstok yang termasuk ke dalam cluster terbaik, selanjutnya adalah menentukan nilai tengah dari atribut RFM dengan nilai tengah atribut RFM dari setiap cluster.

Tabel 16 Nilai rata rata RFM Agen Biasa

\begin{tabular}{|c|c|c|}
\hline $\mathbf{R}$ & $\mathbf{F}$ & $\mathbf{M}$ \\
\hline 25 & 14 & $\operatorname{Rp} 1,608,185.00$ \\
\hline
\end{tabular}

Tabel 17 Nilai rata rata RFM Agenstok

\begin{tabular}{|c|c|c|}
\hline $\mathbf{R}$ & $\mathbf{F}$ & $\mathbf{M}$ \\
\hline 23 & 14 & $\operatorname{Rp} 5,834.160 .00$ \\
\hline
\end{tabular}

Kemudian disusul dengan nilai rata rata pada setiap Cluster Terbaik Agen Biasa dan agenstok. dapat dilihat pada Tabel berikut :

Tabel 18 Nilai rata rata Cluster Terbaik Agen Biasa

\begin{tabular}{|c|c|c|c|c|}
\hline Cluster & Jumlah Customer & R & F & M \\
\hline 1 & 472 & 24 & 16 & $\operatorname{Rp~1,046,784.00~}$ \\
\hline 2 & 61 & 36 & 15 & $\operatorname{Rp~5,952,148.00~}$ \\
\hline
\end{tabular}

Tabel 19 Nilai rata rata Cluster Terbaik Agenstok

\begin{tabular}{|c|c|c|c|c|}
\hline Cluster & Jumlah Customer & R & F & M \\
\hline 1 & 126 & 17 & 15 & $\operatorname{Rp~2,824,079.00~}$ \\
\hline 2 & 26 & 70 & 4 & $\operatorname{Rp~1,708,067.00~}$ \\
\hline 3 & 60 & 14 & 21 & $\operatorname{Rp~20,023,354.00}$ \\
\hline
\end{tabular}

Berikut analisa berdasarkan atribut RFM agen biasa terhadap cluster 2 terbaik :

1. Cluster 1 memiliki simbol rank $\mathrm{R} \uparrow \mathrm{F} \uparrow \mathrm{M} \uparrow$, berdasarkan rata-rata nilai RFM paling tinggi, termasuk kategori Superstar. Kategori Pelanggan Superstar memiliki nilai Recency yang tinggi, Memiliki nilai Frequensi yang tinggi, diantara cluster lainnya, dan Nilai monetary nya tinggi, yang menunjukkan biaya transasksi yang dilakukan berjumlah besar

2. Cluster 2 memiliki simbol rank $\mathrm{R} \downarrow \mathrm{F} \uparrow \mathrm{M} \uparrow$, berdasarkan rata-rata nilai RFM paling tinggi, termasuk kategori Golden. Kategori Pelanggan Golden yang memiliki monetary tertinggi yang kedua, nilai frequency tinggi dan memiliki nilai rata rata transaksi. 
Kemudian dilanjutkan dengan hasil analisa berdasarkan atribut RFM agen biasa terhadap cluster 3 terbaik :

1. Cluster 1 memiliki simbol rank $\mathrm{R} \uparrow \mathrm{F} \uparrow \mathrm{M} \downarrow$, berdasarkan rata-rata nilai $\mathrm{RFM}$, nilai cluster nya berada di nilai rata-rata, maka termasuk kategori Typical. Kategori typical customer memiliki nilai recency tertinggi kedua, Nilai frequency juga tinggi yang berarti sering sering melakukan ttrnsaksi, dan Nilai monetary-nya termasuk nilai rata-rata.

2. Cluster 2 memiliki simbol rank $\mathrm{R} \downarrow \mathrm{F} \downarrow \mathrm{M} \downarrow$, berdasarkan rata-rata nilai R,F,M paling rendah, termasuk kategori Dormant customer. Kategori dormant customer memiliki nilai rata-rata yang rendah, Nilai frequency rendah yang berarti agenstok jarang melakukan transasksi dan Nilai rata-rata monetary rendah.

3. Cluster 3 memiliki simbol rank $\mathrm{R} \uparrow \mathrm{F} \uparrow \mathrm{M} \uparrow$, berdasarkan rata-rata nilai $\mathrm{RFM}$ paling tinggi, termasuk kategori Superstar. Kategori Pelanggan Superstar memiliki nilai Recency yang tinggi, Memiliki nilai Frequensi yang tinggi diantara cluster lainnya dan Nilai monetary nya tinggi, yang menunjukkan biaya transasksi yang di lakukan berjumlah besar.

\section{KESIMPULAN DAN SARAN}

Penelitian ini menghasilkan 2 Cluster Terbaik pada data agen biasa dan 3 Cluster Terbaik pada data agenstok menggunakan Algoritma K-Medoids berdasarkan Davies Bouldin Index (DBI). Hasil DBI terbaik pada Agen biasa terletak pada Cluster 2 dan pada agenstok terletak pada Cluster 3. Dengan masing masing nilai DBI terbaik 0.228 agen biasa dan 0.234 agenstok. Berdasarkan analisa dari nilai tengah rata rata RFM awal dan nilai setiap clusternya maka didapat, diantara 2 Cluster agen biasa, Cluster tertinggi berada pada Cluster 1 dengan kategori pelanggan Superstar yang memiliki loyalitas yang tinggi dengan jumlah 472 pelanggan Dan cluster terendah barada pada cluster 2 yaitu masuk kategori pelanggan golden dengan jumlah 61 pelanggan. Kemudian Cluster tertinggi dari 3 Cluster agenstok berada pada Cluster 3 yaitu dengan kategori pelanggan Superstar yang loyalitasnya tinggi dengan jumlah 60 pelanggan. Dan Cluster agenstok terendah berada Cluster 2 yaitu termasuk kategori Dormant pelanggan dengan jumlah 26 pelanggan.

Untuk penelitian selanjutnya dapat menggunakan data dari studi kasus yang berbeda selain BC HPAI dengan sample data transaksi rentang 1 atau 2 tahun. Kemudian menerapkan metode dan Algoritma yang sama atau menggunakan metode dan algoritma yang baru lainnya yang sesuai dengan permasalahan.

\section{UCAPAN TERIMA KASIH}

Terima Kasih penulis ucapkan kepada pihak kampus khususnya Fakultas Sains dan Ternologi Universitas Islam Negeri Sultan Syarif Kasim Riau yang telah memudahkan dalam penyelesaian Penelitian ini dan juga terima kasih kepada Ibu Siti Monalisa, S.T., M.Kom selaku dosen pembimbing Penelitian, sehingga penelitian ini dapat diselesaikan dengan baik.

\section{DAFTAR PUSTAKA}

[1] Putra, A. S. D., dan Rumyeni, R. (2018). Komunikasi persuasif pt herba penawar alwahida indonesia (hpai) dalam membangun jaringan di kota pekanbaru (Unpublished doctoral dissertation).

[2] Astuti, N. P. M. D., Putra, I. K. M., Kasiani, K., Yudistira, C. G. P. A., dan Widiantara, I. M. (2020). Implikasi penerapan customer relationship marketing dan digital marketing terhadap kepuasan konsumen pada pt gapura angkasa joumpa denpasar. Ganec Swara, 14(1), 506-514.

[3] Cheng, C.-H., dan Chen, Y.-S. (2009). Classifying the segmentation of customer value via $\mathrm{rfm}$ model and rs theory. Expert systems with applications, 36(3), 4176-4184.

[4] Buttle, F. (2008). A crm perspective on nation branding. Nation Branding: Concepts, Issues, Practices, Butterworth-Heinemann, Burlington, MA, 66-74. 
[5] Yohana, N. (2011). Data mining dengan metode fuzzy untuk customer relationship management (crm) pada perusahaan retail. Udayana University, Bali, Indonesia.

[6] Hardiani, T., Sulistyo, S., dan Hartanto, R. (2015). Segmentasi nasabah tabungan menggunakan model rfm (recency, frequency, monetary) dan k-means pada lembaga keuangan mikro. Dalam Seminar nasional teknologi informasi dan komunikasi terapan (semantik) (hal. 463468).

[7] Aktepe, A., Ers" oz, S., dan Toklu, B. (2015). Customer satisfaction and loyalty analysis with classification algorithms and structural equation modeling. Computers \& Industrial Engineering, 86, 95-106.

[8] Sudriyanto,S. (2017). Clustering loyalitas pelanggan dengan metode $\mathrm{rfm}$ (recency, frequency, monetary) dan fuzzy c-means. Prosiding SNATIF, 815-822.

[9] Velmurugan, T. (2012). Efficiency of k-means and k-medoids algorithms for clustering arbitrary data points. Int. J. Computer Technology \& Applications, 3(5), 1758-1764.

[10] Tsiptsis, K. K., dan Chorianopoulos, A. (2011). Data mining techniques in crm: inside customer segmentation. John Wiley \& Sons.

[11] Yulianto, dan Hananto, R. (2018). Panduan sukses referensi utama produk halal dunia.

[12] Prasetyo,E. (2014). Data mining-mengelola data menjadi informasi menggunakan matlab.

[13] Lee, Y. J. (2014). Privacy-preserving data mining for personalized marketing. International Journal of Computer Communications and Networks (IJCCN), 4(1). 